\title{
ARTICLES
}

Submitted 01.23.2014. Approved 04.28.2014

Evaluated by double blind review process. Scientific Editor: Ricardo Ratner Rochman

DOI: http://dx.doi.org/10.1590/So034-759020150510

\section{CROSS-COUNTRY STUDY ON THE DETERMINANTS OF BANK FINANCIAL DISTRESS}

\author{
Estudo cross-country sobre os fatores determinantes da crise financeira bancária \\ Estudio cross-country sobre los factores determinantes de la crisis financiera bancaria
}

\begin{abstract}
Bank failures affect owners, employees, and customers, possibly causing large-scale economic distress. Thus, banks must evaluate operational risks and develop early warning systems. This study investigates bank failures in the Organization for Economic Co-operation and Development, the North America Free Trade Area (NAFTA), the Association of Southeast Asian Nations, the European Union, newly industrialized countries, the $\mathrm{G} 20$, and the $\mathrm{G} 8$. We use financial ratios to analyze and explore the appropriateness of prediction models. Results show that capital ratios, interest income compared to interest expenses, non-interest income compared to non-interest expenses, return on equity, and provisions for loan losses have significantly negative correlations with bank failure. However, loan ratios, non-performing loans, and fixed assets all have significantly positive correlations with bank failure. In addition, the accuracy of the logistic model for banks from NAFTA countries provides the best prediction accuracy regarding bank failure.
\end{abstract}

KEYWORDS | Bank failure prediction, bank, distress, global, cross-country.

\section{RESUMO}

Falências bancárias afetam proprietários, funcionários e clientes, e têm potencial para causar crises econômicas de grande escala. Portanto, os bancos devem avaliar os riscos operacionais e desenvolver sistemas de alerta preventivo. 0 presente estudo investiga falências bancárias na Organização para a Cooperação e Desenvolvimento Econômico, nos países integrantes do Tratado de Livre Comércio da América do Norte (NAFTA, na sigla em inglês), na Associação de Nações do Sudeste Asiático, na União Europeia, em países recentemente industrializados, no G20 e no G8. Utilizamos indicadores financeiros para analisar e explorar a adequação de modelos preditivos. Os resultados demonstram que índices de capital, juros ativos comparados a despesas com juros, receitas excluindo juros comparadas a despesas excluindo juros, rentabilidade sobre o patrimônio e provisões para prejuízos sobre empréstimos têm correlações significantemente negativas com falências bancárias. No entanto, índices de empréstimos, créditos de liquidação duvidosa e ativos fixos têm correlações significantemente positivas com falências bancárias. Além disso, a exatidão do modelo logístico para os bancos dos países que fazem parte do NAFTA fornece melhor precisão em termos de previsão no que diz respeito à falência bancária.

PALAVRAS-CHAVE I Previsão de falência bancária, bancos, crise, global, cross-country.

\section{RESUMEN}

Las quiebras bancarias afectan a los propietarios, empleados y clientes, y pueden causar dificultades económicas a gran escala. Por lo tanto, los bancos deben evaluar los riesgos operativos y desarrollar sistemas de alerta temprana. Este estudio investiga las quiebras bancarias en la Organización para la Cooperación y el Desarrollo Económicos, el Área del Tratado de Libre Comercio de América del Norte (NAFTA, en inglés), la Asociación de Naciones del Sudeste Asiático, la Unión Europea, los países de reciente industrialización, el G20 y el G8. Usamos ratios financieros para analizar y explorar la adecuación de los modelos de predicción. Los resultados muestran que los ratios de capital, ingresos por intereses en comparación con los gastos por intereses, ingresos no por intereses en comparación con los gastos no por intereses, rentabilidad sobre recursos propios y provisiones por riesgos crediticios tienen correlaciones significativamente negativas con la quiebra bancaria. Por otro lado, los ratios de préstamos, préstamos morosos y activos fijos tienen correlaciones significativamente positivas con la quiebra bancaria. Además, la exactitud del modelo logístico de los bancos de los países del NAFTA ofrece la mayor exactitud en la predicción de quiebras bancarias.

PALABRAS CLAVE I Predicción de quiebra bancaria, banco, dificultades, mundial, cross-country. 


\section{INTRODUCTION}

In contemporary economies, banks play a critical role in providing financing channels. Banks operate by obtaining interest from loans. Banks are a crucial medium for stabilizing the financial order and promoting industrial development; consequently, bank failures negatively affect stockholders, employees, customers, and, in some cases, national economies, which may subsequently result in an international financial crisis. The subprime mortgage crisis in the United States in 2007 was the most severe financial crisis since the Great Depression of 1929. Because of the inadequate liquidity of the US banking industry, the Board of Governors of the Federal Reserve System bailed out banks in financial distress. However, the financial distress still affected other countries and led to a global financial crisis that jeopardized the development of the global capital market. How to effectively evaluate bank operations and establish financial early warning systems has been a primary responsibility of competent authorities at financial institutions in all nations. Unpredictable failures frequently occur because the financial status of a bank appears to be stable prior to its failure. The first financial warning system was developed in 1970. Min, Lee, and Han (2006) highlighted that banks' financial warning allowed bank operators to analyze lending decisions and profitability.

It is widely believed that the majority of existing studies on bank failure has relied too heavily on bank-level accounting data (Al-Saleh \& Al-Kandari, 2012; Boyacioglu, Kara, \& Baykan, 2009; Männasoo \& Mayes, 2009; Ravisankar \& Rav, 2010; Serrano-Cinca \& Gutiérrez-Nieto, 2013; Valahzaghard \& Bahrami, 2013; Yildiz \& Akkoc, 2010; Zaghdoudi, 2013). These solutions appear to have shown that financial ratios are more capable of detecting bank distress than other factors. However, most of these studies have considered a single country for analysis (Al-Saleh \& Al-Kandari, 2012; Boyacioglu et al., 2009; Erdogan, 2008; Lanine \& Vennet, 2006; Serrano-Cinca \& Gutiérrez-Nieto, 2013; Sinha, Taneja, \& Gothi, 2009; Valahzaghard \& Bahrami, 2013; Zaki, Bah, \& Rao, 2011).

Different countries have different types of government, culture, laws, and economic development. Banks' operational system and environment also differ substantially from one nation to another and, therefore, cannot be considered equivalent. Huang, Chang, and Liu (2012) first analyzed regional groups' early warning systems for bank finances. However, the results presented only five financial ratios and did not include all countries in each regional group (instances where no data was available were excluded). In addition, Huang et al. (2012) did not conduct various diagnostic tests (such as, e.g., an accuracy evaluation). Thus, they could not conduct analyses regarding the 'reliability' and 'comparability' of banks and predict bank failure in different countries.

We developed an optimal model, evaluated it for accuracy (Divsalar, Javid, Gandomi, Soofi, \& Mahmood, 2011), and compared the early warning indicators of bank failure in the Organization for Economic Co-operation and Development (OECD), the North America Free Trade Area (NAFTA), the Association of Southeast Asian Nations (ASEAN), the European Union (EU), newly industrialized countries (NIC), the G20, and the G8, based on the logistic model (i.e., the variables statistically significant in the model were based on each model).

\section{RELATED LITERATURE}

Altman's (1968) study was the first to predict bankruptcy in banks. Since then, logistic regression (Al-Saleh \& Al-Kandari, 2012; Valahzaghard \& Bahrami, 2013; Zaghdoudi, 2013), genetic algorithms (Martin, Gayathri, Saranya, Gayathri, \& Venkatesan, 2011), multivariate discriminant analysis (Canbas, Cabuk, \& Kilic, 2005; Demyanyk \& Hasan, 2009), multivariate regression analysis (Meyer \& Pifer, 1970), artificial neural networks (Ravi \& Pramodh, 2008), and fuzzy models (Tung, Quek, \& Cheng, 2004; Yildiz \& Akkoc, 2010) have served as general models for predicting bankruptcies.

Bank operations are monitored through financial or operational statuses. The US Federal Deposit Insurance Corporation proposes five components for analyzing bank safety: (a) Capital adequacy is a key component of an operational rating intended to prevent unpredictable loan losses from causing damage to depositors and creditors. (b) Asset quality refers to the evaluation of debtors' ability to repay loans. (c) Management quality refers the evaluation of managers' management capability or structure. (d) Earnings ability refers the evaluation of earnings stability. (e) Liquidity refers to the capability of dealing with distress when abrupt bank runs occur. The composite ratings are referred to as CAMELS.

Several previous studies have investigated whether various financial ratios are effective variables for predicting and explaining a bank failure. Al-Saleh and Al-Kandari (2012) analyzed the first ratio (Investment in Securities to Total Assets), second ratio (Loans to Total Assets), and third ratio (Loans to Deposits), which are considered the best predictors of bank distress. Valahzaghard and Bahrami (2013) found a meaningful relationship between default probability and management quality, earning quality and liquidity quality. Samad (2011) found significant differences in capital adequacy (capital to average total assets, capital to risk weighted assets, equity capital to assets, and Tier 1 capital to risk-weighted assets) between unhealthy and 
healthy banks. Zaghdoudi (2013) also showed that the probability of failure in a bank is decreased when the bank's ability to repay its debt and its banking operations are better and its profitability per employee and leverage are higher.

Adeyeye, Fajembola, Olopete, and Adedeji (2012) indicated that the measures of profitability, liquidity, credit risk and capital adequacy are the key predictive financial ratios. In other words, differences in profitability, liquidity, credit risk (asset quality) and capital adequacy (sustenance) are found to be the major distinguishing characteristics between non-failed (healthy) and failed banks. Overall, the CAMEL components (i.e., its related financial ratios) have been shown to predict bank failures.

\section{METHODOLOGY}

Financial ratios from 2002 to 2012 were collected from the COMPUSTAT database and used to predict failure in banks. The study comprises 772 banks and 6,773 samples and uses a logistic model to construct empirical models. The variables and research model are as follows:

\section{Dependent variables: bank failures}

The definitions of bank distress are primarily based on financial statements. The present study modified the Huang et al. (2012) model, in which a cash flow value lower than the value of liabilities in the current year suggests bank distress. If a bank showed bank distress in year $t$, the value was 1 ; if a bank showed no bank distress in year $t$, the value was 0 .

\section{Independent variables: financial ratios}

Boyacioglu et al. (2009) showed that successful banks had a lower ratio of loans to assets, a higher ratio of net profits to average equity, and a higher ratio of fixed assets to long-term liabilities. Yildiz and Akkoc (2010) stated that healthy banks had higher interest incomes compared to interest expenses, greater non-interest income compared to non-interest expenses, fewer non-performing loans compared to loans, and lower provisions for loan losses compared to loans. However, the empirical results of Serrano-Cinca and Gutiérrez-Nieto (2013) indicated that healthy banks had higher Tier 1 (core) capital compared to average assets.

\section{Control variables: macroeconomic factors}

Macroeconomic indicators can assist in explaining how the environment interacts with bank problems. A substantial drop in GDP growth is a strong indicator that banking problems might emerge (Hutchison \& McDill, 1999). In addition, banking sector distress is increased by falling stock prices (Hutchison \& McDill, 1999), and increasing inflation is accompanied by bank failures (Männasoo \& Mayes, 2009).

\section{Empirical model}

The study used the logistic method. The proxy variables are as follows: CAPITAL ${ }_{j, t}$ is Tier 1 (core) capital compared to average assets in year $t: L O A N_{j, t}$ represents loans compared to assets in year $t ; N P L_{j, t}$ is non-performing loans compared to all loans in year $t ; P L_{j, t}$ is the provision for loan losses compared to all loans in year $t ; F A_{j, t}$ is fixed assets compared to long liabilities in year $t ; R O E_{j, t}$ is net profit compared to average equity in year $t$; IIIE $E_{j, t}$ is interest income compared to interest expenses in year $t$; NINIE $E_{j, t}$ is non-interest income compared to non-interest expenses in year $t$; variable $R G D P_{j, t}$ represents the change in gross domestic product divided by the consumer price index in year $t$; $S T O C K_{j, t}$ denotes the average deviation of the stock index over five years in year $t$; and $C P I_{j, t}$ denotes the consumer price index in year $t$. (all the macro variables in the country where the bank headquarters are located). On the other hand, we tested the predictive aspect of our model up to three years before a failure because we found that further information besides the financial position alone is necessary for a good, fair assessment (Meyer \& Pifer, 1970).

\section{Robustness test}

We tested our model's predictive ability both in- and out-of-sample. We determined four indicators to measure goodness-of-fit, namely sensitivity, specificity, overall predictive capability, and ROC area, and then assessed how satisfactorily the econometric model fit the observed phenomena. We also repeated the same analyses out-of-sample to tackle any sample-specific issues and get more robust and general results. Sensitivity measures the percentage of banks in default that were identified correctly as such. Specificity quantifies the percentage of healthy banks (i.e., not in default) that were identified correctly. Type I and type II errors are closely related to the concepts of sensitivity and specificity. The overall predictive value is the proportion of the sum of all nonfailed and failed banks that were identified correctly to the total number of banks. The ROC curve quantifies the effect of the decision point (used by the model for classification; point $=0.5$ ) on changes in the probability threshold. This curve is the area of a binary classification model; the larger this area, the higher the likelihood of a default case to be correctly identified. 


\section{RESULTS}

Table 1 lists the banks from OECD, NAFTA, ASEAN, EU, NIC, G20, and $\mathrm{G} 8$ countries. The capital ratios in these countries all exceed $6 \%$, with the OECD at $12 \%$ (highest) and the NIC at 8.2\% (lowest). Loans compared to assets ranged from $35 \%$ to $47 \%$, non-performing loans compared to loans averaged approximately $40 \%$, and provision for loan losses compared to loans averaged from $40 \%$ to $50 \%$. These results indicate that credit policies were robust and stable, and that appropriate loan losses are a suitable measure for risk management.

In addition, fixed assets compared to long liabilities were more than $50 \%$ in the OECD and NAFTA, indicating that long liabilities were primarily used to purchase fixed assets, thereby adversely affecting capital movement. The return on equity had a positive value for all groups, with the EU at 15\% (highest), and the G8 at 7\% (lowest). Banks' operating items (e.g., charging clients interest for loans and paying interest on deposits) had a positive value (interest income to interest expenses $>100 \%$ ), with the NIC at $168 \%$ (highest) and the OECD at $125 \%$ (lowest). In addition, banks' non-operating items (irrespective of interest payment/collection on deposits/loans) also had a positive value (non-interest income to non-interest expenses $>100 \%$ ), with the OECD at $142 \%$ (highest) and the NAFTA at $119 \%$ (lowest), indicating that these two items were bank profit sources.

Compared to these variables, the change in real gross domestic product had a positive value in the ASEAN and NIC, indicating that these two groups experienced economic growth; however, the OECD had a negative value (the lowest of all seven groups), indicating an economic recession. Furthermore, the fluctuation of the stock index was lower in the G20, thereby demonstrating a steady capital market. The NIC showed higher stock index fluctuations, indicating that economic growth in the group caused capital from various countries to flow into the stock market, or that transaction and exchange systems were incomplete. Consumer price index in the NIC was high, indicating that the NIC experienced economic growth and a product demand increase.

Table 1. Descriptive statistics: country samples (average values)

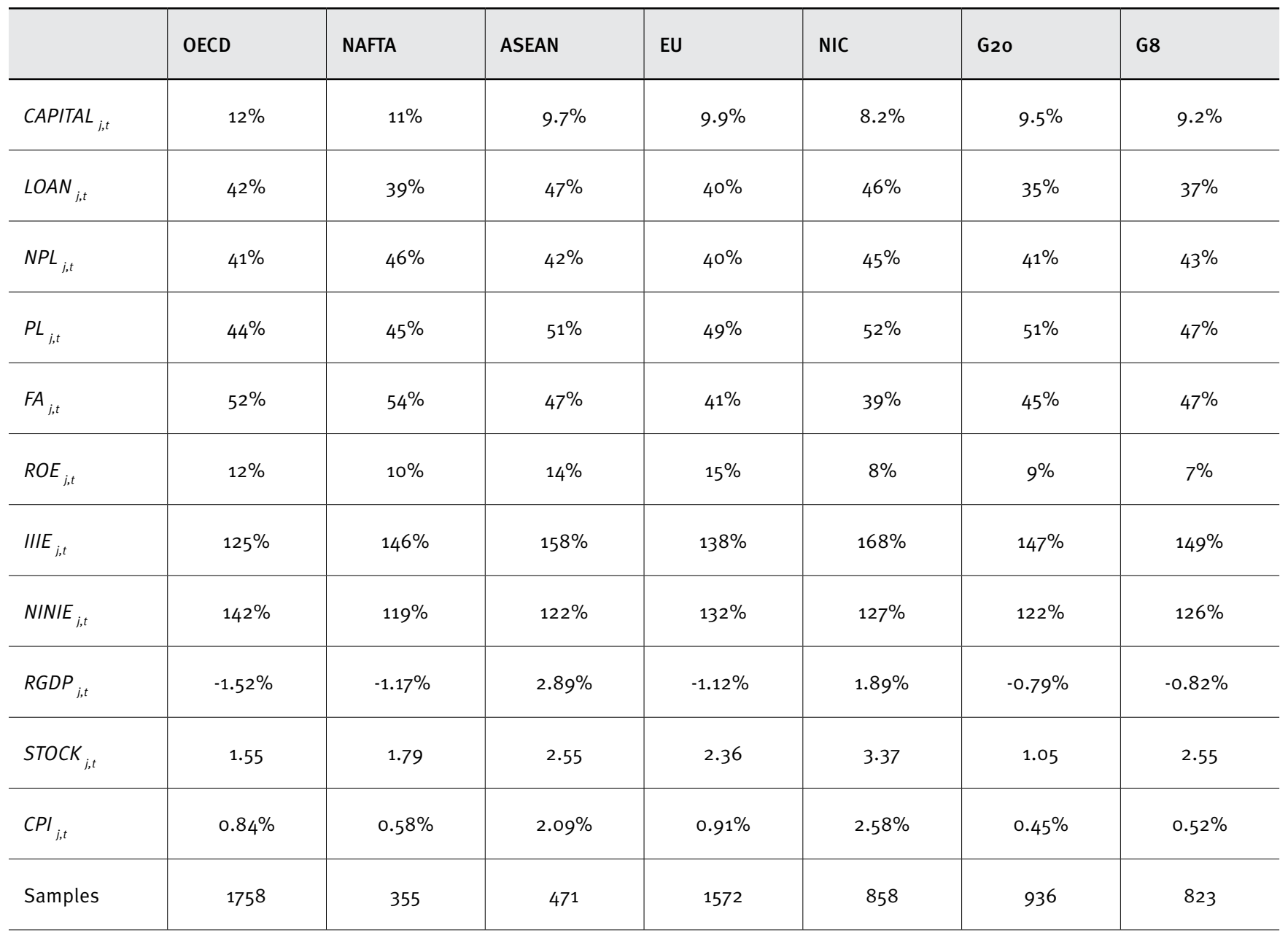


Table 2, Table 3 and Table 4 show that the capital ratio was significantly and negatively correlated to bank distress in banks from ASEAN, NIC, G20, and G8 countries. These results are consistent with those of Serrano-Cinca and Gutiérrez-Nieto (2013) and demonstrate that healthy finances do not occur when banks are experiencing bank distress. The loan ratio was significantly positively correlated with bank distress in the banks from NAFTA, ASEAN, EU, and NIC countries, which supports the results of Boyacioglu et al. (2009).

Table 2. Relationships between financial ratios and bank failure (one year before a failure)

\begin{tabular}{|c|c|c|c|c|c|c|c|}
\hline & OECD & NAFTA & ASEAN & EU & NIC & G20 & G8 \\
\hline Intercept & $-1.058^{\star \star \star}$ & $-4 \cdot 538$ & $2.252^{\star \star \star}$ & 0.276 & $1.621^{\star \star \star}$ & $1.193^{\star \star \star}$ & $-1.5266^{\star \star \star}$ \\
\hline CAPITAL $_{j, t}$ & 0.021 & -0.667 & $-1.478^{\star \star}$ & -0.382 & $-1.917^{\star \star}$ & $-1.552^{\star \star}$ & $-1.981 * *$ \\
\hline $\operatorname{LOAN}_{j, t}$ & -0.075 & $2.675^{\star \star \star}$ & $2.817^{\star \star \star}$ & $1.117^{\star \star \star}$ & $1.623^{\star}$ & 0.047 & -1.55 \\
\hline$N P L_{j, t}$ & $9 \cdot 567^{\star \star \star}$ & $2.135^{\star \star \star}$ & $1.529^{\star \star \star}$ & $1.419^{\star \star \star}$ & $1.677^{\star}$ & -0.658 & 1.028 \\
\hline$P L_{j, t}$ & $-0.218^{\star}$ & 0.115 & 0.085 & $-1.212^{\star \star \star}$ & $-0.812^{\star \star}$ & $-1.209^{\star \star}$ & $-1.659^{\star \star \star}$ \\
\hline$F A_{j, t}$ & 0.019 & -0.029 & $0.119^{\star}$ & 0.018 & $0.957^{\star \star}$ & -0.133 & $0.891^{*}$ \\
\hline$R O E_{j, t}$ & $-1.179^{\star \star}$ & 1.037 & 0.387 & -0.126 & 0.379 & 1.239 & -0.572 \\
\hline$I I I E_{j, t}$ & $-1.655^{\star \star \star}$ & 0.015 & 0.076 & -0.438 & -3.176 & $-2.213^{\star \star}$ & $-1.897^{\star \star \star}$ \\
\hline$N I N I E_{j, t}$ & $-4.627^{\star \star}$ & 0.672 & -0.092 & -0.676 & 0.062 & $-2.156^{\star \star \star}$ & $-2.039^{\star \star \star}$ \\
\hline$R G D P_{j, t}$ & $2.8072^{\star \star *}$ & 0.326 & $-2.139^{\star \star \star}$ & -0.485 & 0.135 & $1.066^{\star \star}$ & $0.487^{\star \star}$ \\
\hline STOCK $_{j, t}$ & $2.106^{\star \star \star}$ & $1.732^{\star \star \star}$ & $1.417^{\star \star \star}$ & $0.891^{\star}$ & $-1.937^{\star \star}$ & -0.0457 & $-1.827^{\star \star \star}$ \\
\hline$C P I_{j, t}$ & $1.035^{\star \star \star \star}$ & -0.029 & 0.039 & $1.199^{\star \star}$ & -0.0929 & $-1.639^{\star \star}$ & 0.125 \\
\hline $\mathrm{x} 2$ & $77.155^{\star \star \star}$ & $58.324^{\star \star \star}$ & $81.757^{\star \star \star}$ & $59 \cdot 584^{\star \star \star}$ & $57.336^{\star \star \star}$ & $62.758^{\star \star \star}$ & $61.472^{\star \star \star}$ \\
\hline Cox and Snell $R^{2}$ & 0.425 & 0.319 & 0.452 & 0.342 & 0.458 & 0.389 & 0.449 \\
\hline Nagelkerke $R^{2}$ & 0.576 & 0.455 & 0.629 & 0.472 & 0.636 & 0.542 & 0.632 \\
\hline Sample & 550 & 127 & 117 & 557 & 277 & 372 & 331 \\
\hline Sensitivity & 0.416 & 0.571 & 0.538 & 0.439 & 0.542 & 0.544 & 0.552 \\
\hline Specificity & 0.471 & 0.632 & 0.635 & 0.406 & 0.489 & 0.476 & 0.465 \\
\hline Overall predictive & 0.449 & 0.598 & 0.581 & 0.420 & 0.516 & 0.513 & 0.511 \\
\hline ROC area & 0.492 & 0.572 & 0.602 & 0.446 & 0.532 & 0.552 & 0.499 \\
\hline
\end{tabular}

Note: ${ }^{* *}$ significant at $1 \%,{ }^{* *}$ significant at $5 \%,{ }^{*}$ significant at $10 \%$. 
Table 3. Relationships between financial ratios and bank failure (two years before a failure)

\begin{tabular}{|c|c|c|c|c|c|c|c|}
\hline & OECD & NAFTA & ASEAN & EU & NIC & $\mathrm{G}_{20}$ & G8 \\
\hline Intercept & $1.538^{\star \star \star}$ & 4.656 & $2.219^{\star \star \star}$ & -0.277 & $-1.659^{\star \star \star}$ & $-1.117^{\star \star \star}$ & $1.587^{\star \star \star}$ \\
\hline CAPITAL $_{j, t}$ & -0.019 & 0.655 & $-1.537^{\star \star}$ & -0.375 & $-1.873^{\star \star}$ & $-1.472^{\star \star}$ & $-1.902^{\star \star}$ \\
\hline$N P L_{j, t}$ & $9.672^{\star \star \star}$ & $2.047^{\star \star \star}$ & $1.491^{\star \star \star}$ & $1.392^{\star \star \star}$ & $1.574^{\star}$ & 0.638 & -1.016 \\
\hline$P L_{j, t}$ & $-0.236^{\star}$ & 0.142 & -0.085 & $-1.194^{\star \star \star}$ & $-0.811^{\star \star}$ & $-1.209^{\star \star}$ & $-1.652^{\star \star *}$ \\
\hline$R O E_{j, t}$ & $-1.093^{\star \star}$ & -1.032 & 0.419 & -0.157 & -0.399 & 1.259 & -0.632 \\
\hline$I I I E_{j, t}$ & $-1.537^{\star \star \star}$ & -0.038 & 0.079 & -0.418 & 3.192 & $-2.189^{\star \star}$ & $-1.935^{\star \star \star}$ \\
\hline$N I N I E_{j, t}$ & $-4.532^{\star \star}$ & 0.732 & -0.112 & 0.671 & -0.092 & $-2.035^{\star \star \star}$ & $-2.132^{\star \star \star}$ \\
\hline$x 2$ & $78.233^{\star \star \star}$ & $62.017^{\star \star *}$ & $81.736^{\star \star \star}$ & $59.127^{\star \star \star}$ & $58.309^{\star \star \star}$ & $61.737^{\star \star \star}$ & $61.336^{\star \star \star}$ \\
\hline Cox and Snell $R^{2}$ & 0.445 & 0.355 & 0.452 & 0.359 & 0.461 & 0.382 & 0.482 \\
\hline Nagelkerke $R^{2}$ & 0.579 & 0.471 & 0.646 & 0.477 & 0.619 & 0.518 & 0.652 \\
\hline Sample & 621 & 108 & 105 & 432 & 262 & 411 & 352 \\
\hline Sensitivity & 0.538 & 0.640 & 0.585 & 0.537 & 0.549 & 0.548 & 0.541 \\
\hline Specificity & 0.591 & 0.552 & 0.594 & 0.555 & 0.525 & 0.522 & 0.539 \\
\hline Overall predictive & 0.562 & 0.593 & 0.590 & 0.546 & 0.539 & 0.535 & 0.539 \\
\hline ROC area & 0.517 & 0.564 & 0.607 & 0.599 & 0.568 & 0.581 & 0.495 \\
\hline
\end{tabular}

Note: ${ }^{* * *}$ significant at $1 \%,{ }^{* *}$ significant at $5 \%,{ }^{*}$ significant at $10 \%$. 
Table 4. Relationships between financial ratios and bank failure (three years before a failure)

\begin{tabular}{|c|c|c|c|c|c|c|c|}
\hline & OECD & NAFTA & ASEAN & EU & NIC & G20 & G8 \\
\hline Intercept & $-1.3368^{\star \star \star}$ & 4.1787 & $2.195^{\star \star \star}$ & 0.294 & $-1.667^{\star \star \star}$ & $-1.139^{\star \star \star}$ & $1.575^{\star \star \star}$ \\
\hline CAPITAL $_{j, t}$ & -0.036 & 0.656 & $-1.539^{\star \star}$ & 0.417 & $-1.892^{\star \star}$ & $-1.477^{\star \star}$ & $-1.872^{\star \star}$ \\
\hline$L O A N_{j, t}$ & -0.072 & $2.534^{\star \star \star}$ & $2.719^{\star \star \star}$ & $1.092^{\star \star \star}$ & $1.587^{\star}$ & 0.049 & -1.37 \\
\hline$N P L_{j, t}$ & $9.681^{\star \star \star}$ & $2.062^{\star \star \star}$ & $1.442^{\star \star \star}$ & $1.389^{\star \star \star}$ & $1.679^{\star}$ & 0.517 & 1.142 \\
\hline$P L_{j, t}$ & $-0.217^{\star}$ & -0.136 & -0.121 & $-1.152^{\star \star \star}$ & $-0.799^{\star \star}$ & $-1.137^{\star \star}$ & $-1.671^{\star \star \star}$ \\
\hline$F A_{j, t}$ & 0.055 & -0.072 & $0.158^{*}$ & 0.061 & $0.952^{\star \star}$ & -0.131 & $0.872^{\star}$ \\
\hline$R O E_{j, t}$ & $-1.092^{\star \star}$ & -1.039 & 0.417 & -0.155 & -0.377 & 1.192 & -0.6515 \\
\hline$I I I E_{j, t}$ & $-1.538^{\star \star \star}$ & -0.019 & 0.078 & -0.452 & 3.136 & $-2.162^{\star \star}$ & $-1.737^{\star \star \star}$ \\
\hline$N I N I E_{j, t}$ & $-4 \cdot 55^{\star \star}$ & 0.612 & -0.089 & 0.662 & -0.077 & $-2.089^{\star \star \star}$ & $-2.125^{\star \star \star}$ \\
\hline$R G D P_{j, t}$ & $2.725^{\star \star \star}$ & 0.302 & $-2.142^{\star \star \star}$ & 0.482 & -0.152 & $1.146^{\star \star}$ & $0.419^{\star \star}$ \\
\hline STOCK $_{j, t}$ & $2.002^{\star \star \star}$ & $-1.619^{\star \star \star}$ & $1.182^{\star \star \star}$ & $0.732^{*}$ & $-1.791^{\star \star}$ & 0.0531 & $-1.737^{\star \star \star}$ \\
\hline$C P I_{j, t}$ & $1.039^{\star \star \star \star}$ & 0.028 & 0.077 & $0.138^{\star \star}$ & 0.068 & $-1.638^{\star \star}$ & -0.158 \\
\hline$x 2$ & $77.366^{\star \star \star}$ & $62.419^{\star \star \star}$ & $85 \cdot 329^{\star \star \star}$ & $59 \cdot 308^{\star \star \star}$ & $55 \cdot 327^{\star \star \star}$ & $61.442^{\star \star \star}$ & $60.779^{\star \star \star}$ \\
\hline Cox and Snell $R^{2}$ & 0.449 & 0.362 & 0.514 & 0.361 & 0.429 & 0.385 & 0.477 \\
\hline Nagelkerke $R^{2}$ & 0.579 & 0.489 & 0.655 & 0.474 & 0.642 & 0.552 & 0.629 \\
\hline Sample & 587 & 120 & 249 & 583 & 319 & 153 & 140 \\
\hline Sensitivity & 0.521 & 0.475 & 0.468 & 0.524 & 0.527 & 0.549 & 0.549 \\
\hline Specificity & 0.525 & 0.475 & 0.537 & 0.493 & 0.474 & 0.549 & 0.518 \\
\hline Overall predictive & 0.523 & 0.475 & 0.502 & 0.510 & 0.502 & 0.549 & 0.536 \\
\hline ROC area & 0.556 & 0.502 & 0.514 & 0.521 & 0.479 & 0.532 & 0.594 \\
\hline
\end{tabular}

Note: ${ }^{* *}$ significant at $1 \%,{ }^{* *}$ significant at $5 \%$, * significant at $10 \%$.

Non-performing loans were significantly and positively correlated to bank distress in the OECD, NAFTA, ASEAN, EU, and NIC, and these results were consistent with the results of Yildiz and Akkoc (2010). Overall, greater flexibility in loan policies increases financial risk in banking. Conversely, loan loss provisions were significantly and negatively correlated to bank distress in the OECD, EU, NIC, G2O, and G8. These results were not consistent with those presented by Yildiz and Akkoc (2010), indicating that loan losses 
can be included in banks' expected lending risks and can serve as a measure for risk management to reduce the possibility of banks distress.

Fixed assets had a significantly positive correlation with bank distress in the ASEAN, NIC, and G8. These results did not support those of Boyacioglu et al. (2009), suggesting that long liabilities are limited by fixed assets and thus detrimental for capital movement, resulting in bank distress. Return on equity had a significantly negative correlation to bank distress in the $O E C D$, and these results were consistent with those of Boyacioglu et al. (2009). Interest income to interest expense ratios and non-interest income to non-interest expense ratios were significantly and negatively correlated to bank distress in the OECD, $\mathrm{G}_{20}$, and $\mathrm{G} 8$, and these results were consistent with those of Yildiz and Akkoc (2010). Results show that bank distress does not occur when banks focus on primary operating items or non-primary operating items.

With regard to macroeconomic factors, the changes in real gross domestic product, the stock index volatility, and consumer product index all had different relationships in the seven regional banking sectors. For example, changes in real gross domestic product showed a significant positive correlation with bank distress in the OECD, G2O, and $\mathrm{G} 8$, changes in real gross domestic product showed a significant negative correlation with bank distress in the ASEAN and a non-significant relationship with bank distress in the NAFTA, EU, and NIC.

Conversely, the stock index volatility had a significant positive correlation to bank distress in the OECD, NAFTA, ASEAN, and $\mathrm{EU}$, a significant negative correlation to bank distress in the NIC and $\mathrm{G} 8$, and a non-significant relationship with bank distress in the $\mathrm{G}_{20}$.

In addition, the consumer product index was both significantly and positively related to bank distress in the OECD and $\mathrm{EU}$, significantly and negatively correlated to bank distress in the $\mathrm{G}_{20}$, and had a non-significant relationship with bank distress in the NAFTA, ASEAN, NIC, and G8. These results demonstrated the differences in cultures, laws and regulations, and economic systems under which various groups and different countries operate.

The optimal results of the logistic model's explicit equation regarding bank distress in regional groups can be expressed using the following financial variables. OECD bank variables are ranked by non-performing loan to loan ratios, provisions for loan losses to loan ratios, ROE, interest income to interest expense ratios, and finally non-interest income to non-interest expense ratios. NAFTA bank variables are ranked by loan to asset ratios and non-performing loan to loan ratios. ASEAN bank variables are ranked by Tier 1 (core) capital to average asset ratios, loan to asset ratios, non-performing loan to loan ratios, and finally, fixed asset to long liability ratios. EU bank variables are ranked by loan to asset ratios, non-performing loan to loan ratios, and finally, provisions for loan losses to loan ratios. NIC bank variables are ranked using the Tier 1 (core) ratios of capital to average assets, loans to assets, nonperforming loans to loans, provisions for loan losses to loans, and fixed assets to long-term liabilities. G2o bank variables are ranked using Tier 1 (core) ratios of capital to average assets, provisions for loan losses to loans, interest income to interest expense, and noninterest income to noninterest expense, whereas $\mathrm{G} 8$ bank variables are ranked by Tier 1 (core) capital to average asset ratios, provisions for loan losses to loan ratios, fixed asset to long liability ratios, interest income to interest expense ratios, and finally, non-interest income to non-interest expense ratios. In addition, the variance inflation factors of variables in our logistic model indicate that the related variables were not collinear.

According to Cox \& Snell $R^{2}$ and Nagelkerke $R^{2}$, banks from the NIC countries have a higher ability to explain the bank failure model proposed in this study, whereas NAFTA banks have a lower ability to explain the model (one year before a failure); G8 banks have a higher ability to explain the bank failure model proposed in this study, whereas NAFTA banks have a lower ability to explain the model (two years before a failure); ASEAN banks have a higher ability to explain the bank failure model proposed in this study, whereas EU banks have a lower ability to explain the model (three years before a failure).

On the other hand, Table 2 also displays the robustness of the prediction model (one year before a failure). Sensitivity was over $50 \%$ (excluding OECD and EU), and highest for the NAFTA at $57.1 \%$. Specificity was over $50 \%$ (only NAFTA and ASEAN), and highest for the ASEAN at $63.5 \%$. The ROC curve area was over $50 \%$ (excluding OECD, EU, and G8). Furthermore, based on regional groups and regarding the accuracy of the logistic model, NAFTA banks performed better (the logistic model's accuracy was $59.8 \%$ ) than other groups. By contrast, EU banks performed worse (the logistic model's accuracy was $42 \%$ ) compared to the other groups.

Table 3 displays the robustness of the prediction model (two years before a failure). Sensitivity was fairly high over $50 \%$, and highest for the NAFTA at $64 \%$. Specificity was also fairly high over $50 \%$, and highest for the ASEAN at $59.4 \%$. The ROC curve area was over 50\% (G8 excluded). Furthermore, based on regional groups and regarding the logistic model's accuracy, NAFTA banks performed better (the logistic model's accuracy was 59.3\%) than other groups. By contrast, $\mathrm{G}_{2} \mathrm{O}$ banks performed worse (the logistic model's accuracy was 53.5\%) when compared to the other groups.

Table 4 displays the robustness of the prediction model (three years before a failure). Sensitivity was over $50 \%$ (excluding NAFTA and ASEAN), and highest for the G20, G8 at $54.9 \%$. Specificity was also over $50 \%$ (excluding NAFTA, EU, and NIC), and highest 
for the $\mathrm{G}_{20}$ at $54.9 \%$. The ROC curve area was over 50\% (excluding NIC). Furthermore, based on regional groups and regarding the logistic model's accuracy, G2o banks performed better (the logistic model's accuracy was 54.9\%) than other groups. By contrast, NAFTA banks performed worse (the logistic model's accuracy was $47.5 \%$ ) compared to the other groups.

Because the financial crisis of 2008 might have restructured the global financial market, we also separated pre- from post-2008 data to obtain the logistic model's accuracy. The comparisons of predicted and actual bankruptcy classifications are shown in Tables 5 to 7. As indicated in Table 5, panel A (one year before a failure), ASEAN banks had the highest value (the logis- tic model's accuracy was 60\%), and NAFTA banks possessed the lowest value (the logistic model's accuracy was 46\%). Moreover, after 2008 (panel B), NIC banks had the highest value (the logistic model's accuracy was 57.9\%), and NAFTA banks showed the lowest value (the logistic model's accuracy was 43.8\%).

As indicated in Table 6, panel A (two years before a failure), NAFTA banks had the highest value (the logistic model's accuracy was $54.00 \%$ ), and EU banks possessed the lowest value (the logistic model's accuracy was 46.9\%). Moreover, after 2008 (panel B), NAFTA banks had the highest value (the logistic model's accuracy was $58.6 \%$, and ASEAN banks presented the lowest value (the logistic model's accuracy was 40.5\%).

Table 5. Robustness test: before and after 2008 (one year before a failure)

\begin{tabular}{|c|c|c|c|c|c|c|c|}
\hline & OECD & NAFTA & ASEAN & EU & NIC & $\mathrm{G}_{20}$ & G8 \\
\hline \multicolumn{8}{|c|}{ Panel A: before 2008} \\
\hline Specificity & 0.550 & 0.472 & 0.542 & 0.489 & 0.571 & 0.580 & 0.524 \\
\hline Overall predictive & 0.546 & 0.460 & 0.600 & 0.526 & 0.551 & 0.588 & 0.547 \\
\hline \multicolumn{8}{|l|}{ Panel B : after 2008} \\
\hline Sensitivity & 0.534 & 0.394 & 0.571 & 0.526 & 0.547 & 0.526 & 0.532 \\
\hline Specificity & 0.538 & 0.484 & 0.559 & 0.489 & 0.436 & 0.467 & 0.563 \\
\hline
\end{tabular}

Table 6. Robustness test: before and after 2008 (two years before a failure)

\begin{tabular}{|c|c|c|c|c|c|c|c|}
\hline & OECD & NAFTA & ASEAN & EU & NIC & $\mathrm{G}_{20}$ & G8 \\
\hline \multicolumn{8}{|c|}{ Panel A: before 2008} \\
\hline Sensitivity & 0.491 & 0.520 & 0.514 & 0.478 & 0.548 & 0.472 & 0.552 \\
\hline Specificity & 0.535 & 0.560 & 0.464 & 0.458 & 0.524 & 0.504 & 0.505 \\
\hline Overall predictive & 0.512 & 0.540 & 0.492 & 0.469 & 0.536 & 0.488 & 0.529 \\
\hline ROC area & 0.495 & 0.584 & 0.506 & 0.512 & 0.509 & 0.492 & 0.554 \\
\hline \multicolumn{8}{|l|}{ Panel B : after 2008} \\
\hline Sensitivity & 0.520 & 0.576 & 0.333 & 0.549 & 0.578 & 0.476 & 0.487 \\
\hline Specificity & 0.503 & 0.600 & 0.476 & 0.459 & 0.507 & 0.493 & 0.514 \\
\hline Overall predictive & 0.512 & 0.586 & 0.405 & 0.506 & 0.540 & 0.484 & 0.500 \\
\hline ROC area & 0.526 & 0.602 & 0.432 & 0.518 & 0.492 & 0.502 & 0.542 \\
\hline
\end{tabular}


Compared to Table 5 and Table 6, as indicated in Table 7, Panel A (three years before a failure), NIC banks had the highest value (the logistic model's accuracy was 54.3\%), and G8 banks presented the lowest value (the logistic model's accuracy was $48.2 \%$ ). Moreover, after 2008 (Panel B), NAFTA banks had the highest value (the logistic model's accuracy was 52.3\%), and OECD banks presented the lowest value (the logistic model's accuracy was $46.2 \%$ ).

Table 7. Robustness test: before and after 2008 (three years before a failure)

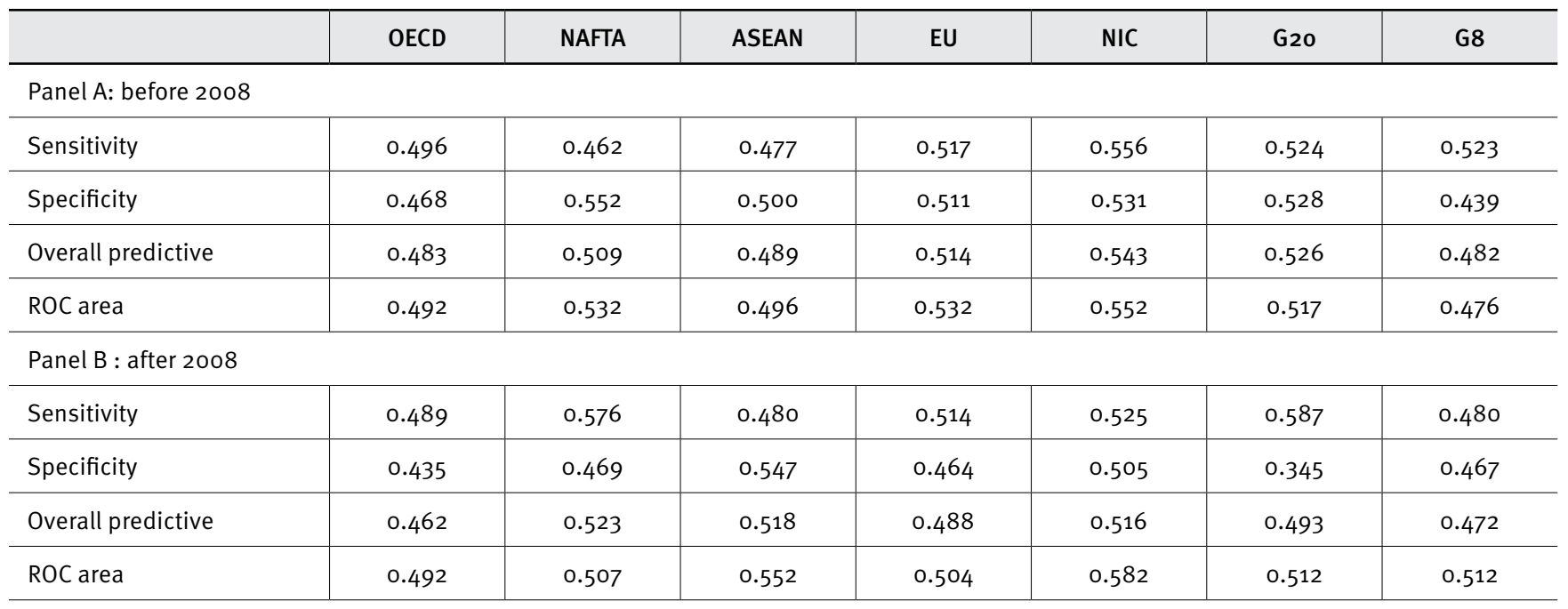

Finally, we have also tested the predictive ability of our model out-of-sample. We repeated the same out-of-sample analyses to tackle any sample-specific issues and get general robust results. The accuracy of the logistic model for NAFTA banks also provides the best prediction accuracy regarding bank failure (one year before a failure). ASEAN banks also had the highest value (one year before a failure, before 2008) or NAFTA banks had the highest value (two years before a failure, after 2008). Overall, the analysis of the prediction model shows all measures of predictive ability, with differences between groups of banks - the Organization for Economic Co-operation and Development (OECD), the North America Free Trade Area (NAFTA), the Association of Southeast Asian Nations (ASEAN), the European Union (EU), the Newly industrialized countries (NIC), the $\mathrm{G} 20$, and the $\mathrm{G} 8$.

\section{CONCLUSION}

This study comprised 772 banks and used data from 2002 to 2012 to analyze the factors that influence financial early warning systems. The results suggested that nonperforming loans have a significantly positive correlation with bank distress in the OECD, whereas provisions for loan losses, return of equity, interest income to interest expenses, and non-interest income to non-interest expenses have a significantly negative correlation. The loan ratio and non-performing loans have a significantly positive correlation with bank distress in the NAFTA. Capital ratio has a significantly negative correlation with bank distress in the ASEAN, whereas the loan ratio, non-performing loans, and fixed assets have a significantly positive correlation. The loan ratio and non-performing loans have a significantly positive correlation with bank distress in the EU, whereas provisions for loan losses have a significantly negative correlation. Capital ratio and provisions for loan losses have a significantly negative correlation with bank distress in the NIC, whereas loan ratio, non-performing loans, and fixed assets have a significantly positive correlation. Capital ratio, provisions for loan losses, interest income to interest expenses, and non-interest income to non-interest expenses have a significantly negative correlation with bank distress in the $\mathrm{G}_{2} \mathrm{O}$. Capital ratio, provisions for loan losses, interest income to interest expenses, and non-interest income to non-interest expenses have a significantly negative correlation with bank distress in the $\mathrm{G} 8$, whereas fixed assets have a significantly positive correlation. In addition, the logistic model's accuracy is higher for NAFTA banks than for other regions (1 year before a failure vs. 2 years before a failure), and the accuracy is higher for $\mathrm{G} 20$ banks than for other regions ( 3 years before a failure). Thus, the empirical results show that the OECD, NAFTA, ASEAN, EU, NICs, G2o, and $\mathrm{G} 8$ have different bank-sector environments.

Most banks are protected by deposit insurance; bank collapses disappear because of government interventions during bank distress. However, banks enter capital markets worldwide; operating risks have been increasing, which disturbs economic stability. Consequently, predicting bank failure plays a critical role 
in the development of contemporary economies and in protecting depositors' funds. The major benefits of predicting bank failure may be that governments can optimize regulations regarding the assessment of bank risks and reduce potential international financial distress.

In sum, we developed cross-country models in the banking industry for forecasting bank failure. The outcomes showed accuracy and good goodness-of-fit. The models and results can serve as a reference to regulators and policy makers regarding both sensitivity and goodness-of-fit. In addition, we adopted a cut-off of under 0.5 points to classify bankrupt banks; however, this value was subjective, and an optimal cut-off should be determined through future study.

\section{REFERENCES}

Adeyeye, P. O., Fajembola, O. D., Olopete, M. O., \& Adedeji, D. B. (2012). Predicting bank failure in Nigeria using principal component analysis and D-Score Model. Research Journal of Finance and Accounting, 3(8), 159-170.

Al-Saleh, M. A., \& Al-Kandari, A. M. (2012). Prediction of financial distress for commercial banks in Kuwait. World Review of Business Research, 2(6), 26-45.

Altman, E. I. (1968). Financial ratios: Discriminant analysis and the prediction of corporate bankruptcy. Journal of Finance, 23(4), 589609. doi: 10.1111/j.1540-6261.1968.tboo843.x

Boyacioglu, M. A., Kara, Y., \& Baykan, O. K. (2009). Predicting bank financial failures using neural networks, support vector machines and multivariate statistical methods: A comparative analysis in the sample of savings deposit insurance fund (SDIF) transferred banks in Turkey. Expert System with Applications, 36(2), 3355-3366. doi:10.1016/j.eswa.2008.01.003

Canbas, S., Cabuk, A., \& Kilic, S. B. (2005). Prediction of commercial bank failure via multivariate statistical analysis of financial structure: The Turkish case. European Journal of Operational Research, 166(2), 528-546. doi:10.1016/j.ejor.2004.03.023

Demyanyk, Y., \& Hasan, I. (2009). Financial crises and bank failures: A review of prediction methods. Omega, 38(5), 315-324. doi:10.1016/j. omega.2009.09.007

Divsalar, M., Javid, M. R., Gandomi, A. H., Soofi, J. B., \& Mahmood, M. V. (2011). Hybrid genetic programming-based search algorithms for enterprise bankruptcy prediction. Applied Artificial Intelligence: An International Journal, 25(8), 669-692. doi:10.1080/08839514.2011.595975

Erdogan, B. E. (2008). Bankruptcy prediction of Turkish commercial banks using financial ratios. Applied Mathematical Sciences, 60(2), 2973-2982.

Huang, D. T., Chang, B., \& Liu, Z. C. (2012). Bank failure prediction models: For the developing and developed countries. Quality and Quantity, 46(2), 553-558. doi:10.1007/s11135-010-9386-9
Hutchison, M., \& McDill, K. (1999). Are all banking crises alike? The Japanese experience in international comparison. Journal of the Japanese and International Economies, 13(3), 155-180. doi:10.1006/ jjie.1999.0427

Lanine, G., \& Vennet, R. V. (2006). Failure predictions in the Russian bank sector with logit and trait recognition models. Expert Systems with Applications, 30(3), 463-478. doi:10.1016/j.eswa.2005.10.014

Männasoo, K., \& Mayes, D. G. (2009). Explaining bank distress in Eastern European transition economies. Journal of Banking and Finance, 33(2), 244-253. doi:10.1016/j.jbankfin.2008.07.016

Martin, A., Gayathri, V., Saranya, G., Gayathri, P., \& Venkatesan, P. (2011). A hybrid model for bankruptcy prediction using genetic algorithm, fuzzy c-means and mars. International Journal on Soft Computing, $2(1), 12-24$.

Meyer, P. A., \& Pifer, H. W. (1970). Prediction of bank failures. Journal of Finance, 25(4), 853-868. doi: 10.1111/j.1540-6261.1970.tboo558.x

Min, S. H., Lee, J., \& Han, I. (2006). Hybrid genetic algorithms and support vector machines for bankruptcy prediction. Expert Systems with Applications, 31(3), 652-660. doi:10.1016/j.eswa.2005.09.070

Ravi, V., \& Pramodh, C. (2008). Threshold accepting trained principal component neural network and feature subset selection: Application to bankruptcy prediction in banks. Applied Soft Computing, 8(4), 1539-1548.

Ravisankar, P., \& Rav, V. (2010). Financial distress prediction in banks using group method of data handling neural network, counter propagation neural network and fuzzy ARTMAP. Knowledge-Based Systems, 23(8), 823-831.

Samad, A. (2011). Is capital inadequacy a factor for bank failure? Evidence from US Banking. Journal of Accounting \& Finance, 11(4), 105-110.

Serrano-Cinca, C., \& Gutiérrez-Nieto, B. (2013). Partial least square discriminant analysis for bankruptcy prediction. Decision Support Systems, 54(3), 1245-1255. doi:10.1016/j.dss.2012.11.015

Sinha, P., Taneja, V. S., \& Gothi, V. (2009). Evaluation of riskiness of Indian banks and probability of book value insolvency. International Research Journal of Finance and Economics, 38, 7-12.

Tung, W. L., Quek, C., \& Cheng, P. (2004). GenSo-EWS: A novel neuralfuzzy based early warning system for predicting bank failures. Neural Networks, 17(4), 567-587. doi:10.1016/j.neunet.2003.11.006

Valahzaghard, M. K., \& Bahrami, M. (2013). Prediction of default probability in banking industry using CAMELS index: A case study of Iranian banks. Management Science Letters, 3(4), 1113-1118. doi:10.5267/j.msl.2013.03.016

Yildiz, B., \& Akkoc, S. (2010). Bankruptcy prediction using neuro fuzzy: An application in Turkish banks. International Research Journal of Finance and Economics, 60, 114-126.

Zaghdoudi, T. (2013). Bank failure prediction with logistic regression. International Journal of Economics and Financial Issues, 3(2), 537543.

Zaki, E., Bah, R., \& Rao, A. (2011). Assessing probabilities of financial distress of banks in UAE. International Journal of Managerial Finance, 7(3), 304-320. doi:10.1108/17439131111144487 